\title{
The Sex Education Method in Agrarian Communities
}

\section{Desriani Desriani, ${ }^{1 *}$ Sofa Muthohar, ${ }^{2}$ Lilif Muallifatul Khorida Filasofa, ${ }^{3}$ Mursid Mursid $^{4}$}

1,2,3,4 Universitas Islam Negeri Walisongo Semarang - Indonesia

Corresponding Author: Shofa Muthohar, email: sofamuthohar @walisongo.ac.id, Jl. Prof. Dr. HAMKA, Km 2, Ngaliyan Semarang 50185

\begin{abstract}
The purpose of this study was to describe how an agrarian society provides sex education. This research was conducted based on the assumption that parents need to teach sex education to early childhood, even though it is taboo, but in a good way. This research is qualitative research with an ethnographic research type. The results showed that 1) The community uses fiqh (rituals of worship) learning methods to cover genitalia and teach the culture of shame from an early age. 2) people still feel it taboo to mention genitals directly. So, they use other terms that are considered not to stimulate crime and are more polite, namely to refer to the penis as sunik, gentog and anu, while the vagina is replaced with the term memek, iwak kebo and anu. 3) people still use the circumcision method for women even though WHO has stated it is prohibited. This study recommends the government and community leaders continue to carry out sex education for children with the correct method according to health, religious, and human rights laws.
\end{abstract}

Keywords: sex education; early childhood; agricultural society; circumcision for girls

\begin{abstract}
Abstrak: Tujuan penelitian ini adalah untuk mendeskripsikan bagaimana masyarakat agraris memberikan pendidikan seks. Penelitian ini dilakukan berdasarkan asumsi bahwa orang tua perlu mengajarkan pendidikan seks kepada anak usia dini, meskipun hal tersebut tabu, namun dengan cara yang baik. Penelitian ini merupakan penelitian kualitatif dengan jenis penelitian etnografi. Hasil penelitian menunjukkan bahwa 1) masyarakat menggunakan metode pembelajaran fiqh (tata cara ibadah) untuk menutupi aurat dan mengajarkan budaya malu sejak dini. 2) masyarakat masih merasa tabu untuk menyebut alat kelamin secara langsung sehingga menggunakan istilah lain yang dianggap tidak memicu tindak kejahatan dan lebih santun yaitu menyebut penis sebagai sunik, gentog dan anu, sedangkan untuk vagina diganti dengan istilah memek. iwak kebo dan anu, 3) masyarakat tetap menggunakan metode sunat untuk wanita meskipun WHO telah menyatakan hal itu dilarang. Penelitian ini merekomendasikan kepada pemerintah dan tokoh masyarakat untuk terus melakukan pendidikan seks untuk anak dengan metode yang benar sesuai kesehatan, agama dan undang-undang hak asasi manusia manusia.
\end{abstract}

Kata Kunci: pendidikan seks; anak usia dini; masyarakat agraris; khitan untukanak perempuan 


\section{A. Introduction}

Sexual harassment is a crime that often occurs in Indonesia. The Witness and Victim Protection Agency (LPSK) ${ }^{1}$ noted that in 2019 there was a $70 \%$ increase in cases $^{2}$ of sexual violence against children compared to 2018, which was 206 to 350 cases. $^{3}$ The topic of sexual harassment itself has received the attention of the community and the government, especially from the Child Protection Commission (KPAI). Still, it has not been able to be maximal in terms of eradicating this sexual crime. Ironically, there were not only adults who suffer from sexual crimes but also children. Even children are easy targets for sex offenders. In some sexual crimes in children, the perpetrators are the people closest to the child, such as friends, teachers, and their own families.

The case that occurred at the Jakarta International School (JIS), according to the Chairman of the National Commission for Child Protection, Seto Mulyadi, became an extraordinary case because the victims of sexual violence reached five children. Children victims of sexual crimes can suffer prolonged trauma, social difficulties, and sexual disorientation as adults, like the case at SDN Tugu 10 Depok on June 8, 2018. Elementary school teachers abused dozens of students. The motivation is revenge for incidents of sexual violence experienced by perpetrators while in elementary school. ${ }^{4}$

Various strategies for sex education in children can be done. Such as campaigns, advocacy, and provision of protection services for victims, but providing an understanding of the culture of protecting oneself from sexual violence is the main thing. Materials for early childhood sex education to stimulate self-protection include my body, clothes, family, and people around, caring for the body, and keeping the body. ${ }^{5}$ Boys and girls are indeed different but not differentiated, resulting in restrictions on children's human rights.

${ }^{1}$ LPSK = Lembaga Perlindungan Saksi dan Korban .

2Lokadata.id, “Kasus Kekerasan Seksual terhadap Anak, 2016-2019," Lokadata.id, 2020, https://lokadata.id/data/kasus-kekerasan-seksual-terhadap-anak-2016-2019-1578639190.

${ }^{3}$ Lokadata.id.

${ }^{4}$ R. Ratna Purnama, "Pernah Korban, Guru SD Pelaku Cabul di Depok ingin Balas Dendam," June 8, 2018, https://metro.sindonews.com/berita/1312782/170/pernah-korban-guru-sd-pelakucabul-di-depok-ingin-balas-dendam.

${ }^{5}$ Tri Endang Jatmikowati, Ria Angin, and Ernawati Ernawati, "Model dan Materi Pendidikan Seks Anak Usia Dini Perspektif Gender untuk Menghindarkan Sexual Abuse," Jurnal Cakrawala Pendidikan 3, no. 3 (2015): 437-48, https://doi.org/10.21831/cp.v3i3.7407; Dwi Ario Fajar, Susanto 
During this time, sex education for early childhood is still considered taboo by the community. Many people assume that sex education has not been appropriate for children. Even though sex education provided to children since childhood is very influential in the lives of children when they are teenagers and adults-especially children, now able to think critically, in terms of questions and behavior. Early childhood has a very rapid development. Child development occurs in a child with various aspects, including physical (motor), emotional, cognitive, and psychosocial aspects (how children interact with the environment). Questions that children ask sometimes make parents overwhelmed in answering questions about sexuality, such as where I come from, why I have different sexuality from other people. ${ }^{6}$

When children ask parents about something considered taboo by parents, the parents themselves will often change the subject; sometimes, they shout and forbid children from asking taboo questions. ${ }^{7}$ In addition, sometimes, the answers given may seem inconsequential even though such an answer can trigger a child to explore on his own if he does not get an answer from his parents. Parents have an essential role in sex education in children because children are entitled to get information about sex education. Children also have the right to protect themselves from sexual harassment, early pregnancy and maintain the health of their bodies and reproductive organs. ${ }^{8}$

Sex education is the teaching, awareness, and provision of information about sex. ${ }^{9}$ Information provided knowledge about the function of the reproductive organs by instilling morals, ethics, commitment, religion. The hope is that they will not "abuse" the reproductive organs. Psychologists teach that

Susanto, and Ribut Achwandi, "Strategi Optimalisasi Peran Pendidikan Seks Usia Dini di PAUD dalam Menanggulangi Pelecehan Seks terhadap Anak di Pekalongan," Jurnal Litbang Kota Pekalongan 7 (2019).

6Inhastuti Sugiasih, "Need Assessment Mengenai Pemberian Pendidikan Seksual yang Dilakukan Ibu untuk Anak Usia 3-5 Tahun," Proyeksi 6, no. 1 (2011): 71-81.

${ }^{7}$ Syarifah Gustiawati Mukri, "Pendidikan Seks Usia Dini dalam Derspektif Hukum Islam," Mizan: Journal of Islamic Law3, no. 1 (2018): 1-20, https://doi.org/10.32507/mizan.v3i1.153.

${ }^{8}$ Atreya Senja, Pendidikan Seks Tanggung Jawab Siapa? The Important of Sex Education for Kids (Yogyakarta: Brilliant, 2020), 15-16.

${ }^{9}$ Risa Fitri Ratnasari and M. Alias, "Pentingnya Pendidikan Seks untuk Anak Usia Dini," Tarbawi Khatulistiwa: Jurnal Pendidikan Islam 2, no. 2 (2016): 55-59, https://doi.org/10.29406/ tbw.v2i2.251. 
children from an early age should be introduced to sex education according to their maturity stage.

According to Sigmund Freud, the stages of sex development consist of five phases: 1) Oral stage; in this phase, a child gets pleasure through his mouth when he is breastfeeding and sucking milk through his mother's nipples. This phase starts from infancy to the age of 0-2 years. At this age, a child seems very enthusiastic about putting anything in his mouth. 2) Anal stage, satisfaction, and a pleasant change from the mouth to the anal area and its surroundings such as the urethra. The pleasure and satisfaction felt when a child is holding urine and defecating. 3) Phallic stage This phase of children begin to understand that their genitals have different siblings or friends. This phallic phase takes place when the child enters around the age of 3-7 years. Feeling of pleasure that lasts when the genitals experience touch or palpation. 4) Latency stage This phase occurs around the age of 7-11 years. At that age range, the sexual behavior of a child seems to be buried with new activities, playing, homework and school. They get tired and sleep quickly to get up early, go to school, and 5) genital stage, this phase occurs at around 12-18 years. In this phase, the process of psychosexual development reaches its final point. Sexual organs become active as sexual hormones begin to function, so physical and psychological changes occur. ${ }^{10}$

Must be careful. In the phallus stage, the child has begun to understand that his genitals are different from his brother, sister, or friends. ${ }^{11}$ In this phallus phase, the child will feel the pleasure of when his genitals experience touch or palpation. In this phase, there is an erotic feeling of children towards parents of different sexes. Curiosity about things that have sex can be seen in children's behavior, for example, opening her mother's skirt, touching her breasts, or holding the genitals of her parents. In addition, a boy's erotic power towards his mother, accompanied by jealousy towards his father and wanting to change his father's position next to his mother, or often called the Oedipus complex. At the same time, girls are called electro complexes, which are accompanied by a feeling of inferiority because they do not have genitals like boys and feel afraid if there is damage to the genitals. If the oedipus and electra complex cannot be 11-14.

${ }^{10}$ Safrudin Aziz, Pendidikan Seks Anak Berkebutuhan Khusus (Yogyakarta: Gava Media, 2015),

${ }^{11}$ Aziz, 30. 
adequately resolved, it can cause emotional disturbances to the child in the future. ${ }^{12}$

Teaching sex education to children is certainly not easy. Sex education material is also different for teenagers or adults. Before teaching sex education to children, it is necessary to know the scope of sex education. Here is some sex learning in early childhood: 1) Introducing body parts and their functions; 2) Teaching children about which parts of the body may be touched and which cannot be touched by others; 3) Introducing genitals according to their name; 4) Teach children to maintain the health of their genitals; 5) Introducing children to the limits of male and female genitalia. Some parents should already have taught children about the name of the genitals according to their name and function. In sex education for early childhood, parents do not be ashamed to mention the vagina or penis in front of children. Is not that part of the body, as well as the hands or feet? Introduce the child to all parts of his body and their functions. ${ }^{13}$ They can learn about sex education material that covers the themes of me and my body, family and people around me, me and my clothes, how to care for the body, and how to look after the body. ${ }^{14}$

Several studies mentioned that knowledge about sex education for early childhood and the method is still fundamental. Research conducted by Daviq Chairilsyah on Sex Education In The Context Of Early Indonesian Childhood shows that violence and abuse against children in Indonesia are still very high. Data from the Indonesian Child Protection Commission (KPAI) for 2015-2019 shows that violence against children has increased significantly. One reason is that many families have not paid attention to sex education for their children. ${ }^{15}$ This knowledge is more important to emphasize for families that have a low level of education. Research by Umi Latifah and Lita Latiana examined parents' ability with different educational backgrounds in the Jepara district in 2017, concluding that there were significant differences between parents with primary, secondary, and higher education backgrounds regarding sex

\footnotetext{
${ }^{12} \mathrm{Aziz}, 30$.

${ }^{13}$ Chomaria Nurul, Pendidikan Seks untuk Anak (Solo: Aqwam, 2012), 27.

${ }^{14}$ Jatmikowati, Angin, and Ernawati, "Model dan Materi Pendidikan Seks Anak Usia Dini Perspektif Gender untuk Menghindarkan Sexual Abuse."

15Daviq Chairilsyah, "Sex Education in the Context of Indonesian Early Childhood," International Journal of Educational Best Practices 3, no. 2 (2019): 41-51, https://doi.org/10.31258/ ijebp.v3n2.p41-51.
} 
education for early childhood. ${ }^{16}$ The research on the innovation of sex education methods for early childhood is presented in Nor Laily et al., who conveyed the Mantuku education method. It uses a robot to explain the sexual organs of children that must be protected so that children can easily understand sex education material, which includes knowledge of sexual violence, awareness of the dangers of sexual violence, and the ability to protect themselves from sexual violence. ${ }^{17}$ The development of this method may be readily accepted in urban communities, but in rural communities, it will be different. This research shows the agrarian society culture of sex education for children. The need for continuous innovation in providing knowledge to the public is about sex education for children and its methods. This development certainly does not conflict with health science, religious values, and the culture of an agrarian society.

This research uses a qualitative research method with ethnographic type. Qualitative research aims to obtain in-depth data that contains meaning. Meaning is actual data, factual data, which is a value behind the visible data. ${ }^{18}$ According to the time, context, and location where the community lives, the truth can be very subjective. ${ }^{19}$ The sample data source was selected purposively and snowball sampling. ${ }^{20}$ Primary data sources are residents of Kedungmulyo Village, Jakenan Subdistrict, Pati Regency, who have children aged 3-6 years. Secondary data are documentation data, interview transcripts from the community, and books that support this research. In this study, researchers focused on sex education for early childhood in an agrarian society, including how the parents' method of providing sex education to early childhood in an agricultural community in Kedungmulyo village, Jakenan sub-

16Umi Faizah and Lita Latiana, "Parents Knowledge about Early Childhood Sexual Education Based on Level of Education in Krasak Village, Pecangaan Sub-District, Jepara District," Early Childhood Education Papers (Belia) 6, no. 2 (2017): 59-62.

${ }^{17}$ Nor Laili et al., "Mantuku (Manekin Tubuhku: As an Adaptive Media for Sex Education to Toddlers)," in Proceedings of the 1st International Conference on Early Childhood Care Education and Parenting (ICECCEP 2019) (Paris: Atlantis Press, 2020), https://doi.org/10.2991/assehr.k. 201205.102.

${ }^{18}$ Sugiyono, Metode Penelitian Pendidikan Pendekatan Kuantitatif, Kualitatif dan R\&D (Bandung: Alfabeta, 2007), 3.

${ }^{19}$ Norman K. Denzin and Yvonna S. Lincoln, The SAGE Handbook of Qualitative Research (Thousand Oaks: SAGE Publications Inc, 2009).

${ }^{20}$ Sugiyono, Metode Penelitian Pendidikan Pendekatan Kuantitatif, Kualitatif dan R\&D, 400. 
district, Pati regency. The data collection techniques in this study are interview, observation, and documentation. Test the validity of the data through triangulation. The qualitative data analysis process takes place during the interactive data collection process with interactive analysis. The resource persons confirm deductive, inductive researcher analysis of the research data, and conclusions are drawn.

\section{B. Islamic Sex Education in Agrarian Society}

Sex education with a western paradigm is often unacceptable to Indonesian society because it provides information about sex and prevention efforts on pregnancy and transmission of venereal disease. The purpose of sex education is less complete because it does not involve morality. Giving information about the meaning and function of reproduction or the use of drugs in the program to prevent pregnancy without character can plunge children into free sex. ${ }^{21}$ Therefore, it is essential to involve religious and cultural values so that sex education is complete as an effort to protect children from violence and sexual disorders.

Islam has its views in terms of sex education. According to Yusuf Madani, from the explanation of the Koran, sunnah, and Islamic Jurisprudence books, it was found that sexual education in Islam is not limited to adults. Islam stipulates to train children to be able to adapt well to sexual attitudes from the age of tamyiz. ${ }^{22}$

In the Hadith, Rasulullah said, men should not see the aurat of other men, and women should not know the aurat of other women. And a man may not sleep with another man in one blanket, and a woman may not sleep with another woman in a blanket (HR. Turmudzi). ${ }^{23}$

This hadith can be used as material to teach sex education to children. Muslims can teach children always to maintain their aurat/genitals. Parents must give the habit of children to sustain genitalia since childhood. Keeping aurat will keep children away from sexual crimes. ${ }^{24}$

\footnotetext{
${ }^{21}$ Aziz, Pendidikan Seks Anak Berkebutuhan Khusus, 30.

${ }^{22}$ Madani Yusuf, Pendidikan Seks Untuk Anak dalam Islam Panduan bagi Orang Tua, Guru dan Kalangan Lainnya, trans. Iwan Kurniawan and Yudi Yudi (Jakarta: Pustaka Zahra, 2003), 24.

${ }^{23}$ Imam An Nawawi, Syarah Shahih Muslim Tahqiq \& Takhrij, ed. Isham Ash-Shababithi and Hazim Muhammad (Jakarta: Pustaka Azzam, 2011), 152-153.

${ }^{24}$ Senja, Pendidikan Seks Tanggung Jawab Siapa? The Important of Sex Education for Kids, 117-18.
} 
Islam views sex as something that is not taboo to be discussed, but rather it is an important thing to teach. ${ }^{25}$ Thus, Islam itself never forbids or taboos sex education. But Islam encourages parents to teach sex education to children according to their age.

Agricultural society has a unique character. One of the characteristics of agrarian society is conservative; they are usually closed and difficult to accept, likewise, with sex education. The agricultural community is still closed and thinks that sex is a taboo that should not be discussed with children. Sometimes a person feels uncomfortable when peeling sex. If so, the study of sex needs to be formulated with the right portion and target to achieve the primary goal of protecting children from sexual crimes and avoiding sexual deviations.

Nearly half of Kedungmulyo Village, Jakenan District, Pati Regency is working as a farmer. Located in Jakenan Subdistrict and bordered by several villages, namely, the north is bordered by Ngastorejo village, east is bordered by Tlogorejo village, Degan and Mintobasuki Village border south. The distance from Kedungmulyo village to Pati City is $6.1 \mathrm{~km}$. General data of Jakenan subdistrict is located in the eastern part of Pati Regency (about $16 \mathrm{~km}$ east of Pati City). Located at an altitude between 10-25 meters above sea level. Precisely located at coordinates $6^{\circ} 45^{\prime \prime} 0$ ? LS, $111^{\circ} 11^{\prime \prime} 0$ ? BT - $7^{\circ} 4$ "29? LS, $111^{\circ} 9 " 3$ ? BT. The whole area is located in the lowlands with alluvial-type soil. The western region is a Juwana river basin where floods occur every year during the rainy season due to the overflow of the Juwana river. In early 2008, floods submerged the western area of Jakenan District to a depth of 3.5 meters that lasted for more than one month. ${ }^{26}$

Most of the Kedungmulyo villagers depend on agriculture for rainfed land. Even though it is close to the Juwana river, they cannot use river water during the dry season because it is mixed with seawater to taste salty. Meanwhile, during the rainy season, their fields are often flooded. Many people choose to migrate to other areas such as Jakarta, Sumatra, and even abroad.

The parents who leave will leave their children with relatives or grandmothers. So that these overseas parents cannot fully educate or monitor

\footnotetext{
${ }^{25}$ Kharisul Wathoni, "Persepsi Guru Madrasah Ibtidaiyah tentang Pendidikan Seks bagi Anak (Studi Kasus di MI Se-Kecamatan Mlarak)," Kodifikasia 10, no. 1 (2016): 203-27, https://doi.org/ 10.21154/kodifikasia.v10i1.814.

26“Jakenan," patikab.go.id, 2014, https://www.patikab.go.id/v2/id/2009/11/19/jakenan/.
} 
the development of their children directly. Communities in Kedungmulyo village, including conservatives, are still taboo if they have to talk about sexuality. They are religious people who obey and uphold existing norms and customs. $^{27}$

Farmers are often referred to as innocent and not up to date with social developments. There is no exception with sexual education for early childhood. Very few of the peasant communities consider this education necessary. Some even think that sexual education will plunge children into bad things because it is too early to introduce. ${ }^{28}$ Among busy parents, they chose to submit sex education to the school. By sending their children to school at school, parents no longer feel the need to teach about sex education.

The methods used by parents to teach sex education to children from an early age include lecture methods and methods of habituation, and parents instill shame, courtesy from an early age on children. This is in line with the statement of Lely Camelia and Ine Nirmala, which states that guilt must be instilled in children from an early age, do not make it a habit for children even though they are still naked in front of others. ${ }^{29}$

\section{Family Education Patterns in Agricultural Societies}

Parenting is carried out in the family is vital in applying methods of sex education provided by parents to children. The emotional relationship arises because the love affair in the family is the essential element for children's development. The parenting applied in the planting of sex education for young children in Kedungmulyo village, Jakenan sub-district, on average, uses a democratic parenting style. Parents recognize the child as a person and are involved in decision-making. Parents themselves prioritize the interests of children but are still controlled. Parents give freedom to children to choose and

\footnotetext{
27 “Kedungmulyo, Jakenan, Pati,” n.d., https://id.m.wikipedia.org/wiki/Kedungmulyo,_Jakenan,_ Pati.

${ }^{28}$ Meiga Kurniasari, Siti Istiyati, and Kartono Kartono, "Pandangan Masyarakat Tani Mengenai Sex Education untuk Anak Usia Dini di Desa Samiran Kecamatan Selo Kabupaten Boyolali,” Kumara Cendekia 7, no. 1 (2019): 26-40, https://doi.org/10.20961/kc.v7i1.35630.

${ }^{29}$ Lely Camelia and Ine Nirmala, "Penerapan Pendidikan Seks Anak Usia Dini menurut Perspektif Islam (Upaya Pencegahan Kekerasan dan Pelecehan Seksual terhadap Anak Usia Dini melalui Penerapan Pendidikan Seks dalam Perspektif Sunnah Rasul)," Yaa Bunayya: Jurnal Pendidikan Anak Usia Dini 1, no. 1 (2017): 27-32, https://doi.org/10.24853/yby.1.1.27-32.
} 
take action, such as selecting clothes and choosing toys according to existing norms. ${ }^{30}$

In addition to democratic parenting, several families apply authoritarian parenting, such as in Ry's mother and Tt's mother. In this authoritative parenting, parents do not introduce compromise with children. Children must obey all parental orders, and if children do not follow their parents, the parents will punish the children. In this authoritarian parenting style, parental control of children is rigorous. ${ }^{31}$

Early childhood sex education in Kedungmulyo village, Jakenan subdistrict, Pati Regency uses lecture, example, habituation, and culture methods. The lecture method is that parents give advice or direct advice to children about what can and should not be done. The exemplary method is that parents become role models or explicit examples for their children; for example, a child will use the hijab when he sees his mother wearing the hijab. And the last is the habituation method, where parents teach children what things they should do, and it repeats every day. For example, parents teach children to clean their genitals both after bowel movements and urination. The community realizes that the children in an agrarian society are different from the children in the city. Not many questions about sexuality came out of the child. They are still innocent because parents limit children from playing with gadgets and playing with their friends around the house under parental supervision. ${ }^{32}$

The Kedungmulyo village community incorporates sex education for children through religious materials at Madrasah Diniyah, packaged in Fiqh lessons. In jurisprudence, the boundaries of rules regarding the role and function of gender are conveyed between men and women. ${ }^{33}$ Parents still feel it taboo to introduce the name of the genitals following the name of the child. So parents use other terms to introduce the name of the genitals to the child. To maintain their decency, they call their genitals with obscure words such as sunik, gentong, manuk, and anu for the names of male genitals. As for the name of the female genitals is called memek', iwak kebo, and anu. ${ }^{34}$

\footnotetext{
${ }^{30}$ Prt, Smrh, and Msrh, Interview, 9 /6 2020.

${ }^{31} \mathrm{Ry}$ and Tt, Interview, May 31, 2020.

${ }^{32} \mathrm{Tt}$ and Prt, Interview, June 9, 2020.

${ }^{33} \mathrm{Ky}$, Interview, July 16, 2020.

${ }^{34}$ Prt and Smr, Interview, July 15, 2020.
} 


\section{Culture of Circumcision of Girls Need to Change}

Based on the results of field research, researchers found that the rural community in Kedungmulyo Village, Jakenan District, Pati Indonesia District still practices circumcision for girls. The community implements the culture of female circumcision containing religious learning, namely, independence, shame, courtesy, and closing genitalia. Parents always advise children, set a good example, and get children to close their genitals. ${ }^{35}$ The method of discussion used in habituation in Kedungmulyo village is sufficient to follow parents' expectations that children can behave well and avoid sexual harassment and violence.

For the Kedungmulyo community, girls are "obliged"36 to circumcise as boys. Society believes that if a girl is not circumcised, they are worried about their daughter about a big appetite that tends to make the child develop poorly. The community expects their daughters to be children who know good manners, diligently worship, and not be naughty children as people of "East Java". They assume that the women of "East Java" have no circumcision, so "naughty". 37

Girls have had to circumcise since they were 3 or 4 years old; the sooner, the better. For example, a child named ZP from Mrs. SR was circumcised at the age of 3 months. They believe that circumcised girls will grow up with controlled libido so that they become shalihah children. Whereas boys at the average age of circumcision at the age of 10 aim to not interfere with growth. ${ }^{38}$ The circumcision of girls using salvation as a celebration for boys. They use the services of traditional healers and doctors, depending on the insight of their parents. Traditional families usually use the services of traditional healers, while more modern families use the services of doctors. They bring 'offerings' given to the child and the shaman or doctor. The hope is that the circumcision procession runs smoothly and can achieve the intended purpose. Circumcision culture of this girl has become a culture and is carried out by all citizens, so it is almost sure that the girls of Kedungmulyo are circumcised. ${ }^{39}$

35Masrokhah and Tuti, interview, September 6, 2020.

${ }^{36}$ Ashabul Fadhli, "Meramu Ketentuan Hukum Islam Terkait Khitan Perempuan," Juris Jurnal Ilmiah Syariah) 14, no. 1 (2015): 47-61, https://doi.org/10.31958/juris.v14i1.296.

37Prt and Smr, interview, July 15, 2020.

38Prt, Smr, and Sr, interview, July 15, 2020.

${ }^{39}$ Ms. Prt, Smr, SM, JM, Mr. Srt, Ms. SR, interview, July 14, 2020. 
This culture may seem contradictory between hurting children and the moral desire to provide sex education and children's independence. The community needs to teach religious values, namely freedom, shame, courtesy, and covering one's genitals. Parents always try to advise children, set a good example, and persuade children to cover their genitals. Perhaps, one culture of female circumcision needs to change towards a more humane way. In contrast, other ways considered good are sex education using religious education methods, differentiating the roles of men and women, and using polite terms.

The female circumcision culture is still practiced in the north coast of Central Java, from Demak to Pati, ${ }^{40}$ even though the World Health Organization (WHO) states that this violates human rights for girls. ${ }^{41}$ In fact, in February 2020, WHO said that International Day did not tolerate female circumcision (International Day of Zero Tolerance for female genital mutilation). ${ }^{42}$ The female circumcision culture needs to be studied in depth because it has to do with religious beliefs in the north coast region of Central Java. Need more research and deepening so that the community is more open, especially those involving spiritual experts. If this is a crime against girls, it is also necessary to study it religiously and be socialized.

\section{E. Conclusion}

The teaching of sex education is intended to protect children from sexual crimes that can target them at any time, to avoid sexual disorientation and ensure equal treatment of rights between boys and girls. The results showed that 1 ) the community uses fiqh (rituals of worship) learning methods to cover genitalia and teach the culture of shame from an early age, 2) people still feel it taboo to mention genitals directly, so they use other terms that are considered not to stimulate crime and are more polite, namely to refer to the penis as sunik, gentog and $a n u$, while for the vagina is replaced with the term memek, iwak

\footnotetext{
${ }^{40}$ Jauharotul Farida et al., "Sunat pada Anak Perempuan (Khifadz) dan Perlindungan Anak Perempuan di Indonesia: Studi Kasus di Kabupaten Demak," Sawwa: Jurnal Studi Gender 12, no. 3 (2018): 371-96, https://doi.org/10.21580/sa.v12i3.2086.

41 "Female Genital Mutilation," 2020, https://www.who.int/news-room/fact-sheets/ detail/female-genital-mutilation; Unite for Children - Unicef, "Female Genital Mutilation/Cutting: A Global Concern” (New York, 2016), http://unfpa.org.co/.

42"International Day of Zero Tolerance for Female Genital Mutilation," 2020, https:// who.int/news-room/events/detail/2020/02/06/default-calendar/international-day-of-zerotolerance-for-female-genital-mutilation.
} 
kebo and $a n u, 3$ ) people still use the circumcision method for women even though WHO has stated it is prohibited.

This study recommends the government and community leaders continue to carry out sex education for children with the correct method according to health, religious, and human rights laws. Specifically, regarding the culture of female circumcision, the researcher hopes that the government and community leaders can rethink the positive and negative impacts. The important thing is that parents or teachers need to include religious material in sex education for children after an early age to achieve the goals of sex education to protect children from sex crimes, prevent sexual disorientation, and equal rights between men and women.[s]

\section{References}

Aziz, Safrudin. Pendidikan Seks Anak Berkebutuhan Khusus. Yogyakarta: Gava Media, 2015.

Camelia, Lely, and Ine Nirmala. "Penerapan Pendidikan Seks Anak Usia Dini menurut Perspektif Islam (Upaya Pencegahan Kekerasan dan Pelecehan Seksual terhadap Anak Usia Dini melalui Penerapan Pendidikan Seks dalam Perspektif Sunnah Rasul)." Yaa Bunayya: Jurnal Pendidikan Anak Usia Dini 1, no. 1 (2017): 27-32. https://doi.org/10.24853/yby.1.1.27-32.

Chairilsyah, Daviq. "Sex Education in the Context of Indonesian Early Childhood." International Journal of Educational Best Practices 3, no. 2 (2019): 41-51. https://doi.org/10.31258/ijebp.v3n2.p41-51.

Denzin, Norman K., and Yvonna S. Lincoln. The SAGE Handbook of Qualitative Research. Thousand Oaks: SAGE Publications Inc, 2009.

Fadhli, Ashabul. "Meramu Ketentuan Hukum Islam terkait Khitan Perempuan." Juris Ournal Ilmiah Syariah) 14, no. 1 (2015): 47-61. https://doi.org/10.31958/ juris.v14i1.296.

Faizah, Umi, and Lita Latiana. "Parents Knowledge about Early Childhood Sexual Education Based on Level of Education in Krasak Village, Pecangaan Sub-District, Jepara District." Early Childhood Education Papers (Belia) 6, no. 2 (2017): 59-62.

Fajar, Dwi Ario, Susanto Susanto, and Ribut Achwandi. "Strategi Optimalisasi Peran Pendidikan Seks Usia Dini di PAUD dalam Menanggulangi Pelecehan Seks terhadap Anak di Pekalongan." Jurnal Litbang Kota Pekalongan 7(2019).

Farida, Jauharotul, Misbah Zulfa Elizabeth, Moh Fauzi, Rusmadi Rusmadi, and Lilif Muallifatul Khorida Filasofa. "Sunat pada Anak Perempuan (Khifadz) dan Perlindungan Anak Perempuan di Indonesia: Studi Kasus di Kabupaten Demak." 
Sawwa: Jurnal Studi Gender 12, no. 3 (2018): 371-96. https://doi.org/ 10.21580/sa.v12i3.2086.

"Female Genital Mutilation," 2020. https://www.who.int/news-room/fact-sheets/ detail/female-genital-mutilation.

"International Day of Zero Tolerance for Female Genital Mutilation," 2020. https://www.who.int/news-room/events/detail/2020/02/06/defaultcalendar/international-day-of-zero-tolerance-for-female-genital-mutilation.

patikab.go.id. “Jakenan,” 2014. https://www.patikab.go.id/v2/id/2009/11/19/ jakenan/.

Jatmikowati, Tri Endang, Ria Angin, and Ernawati Ernawati. "Model dan Materi Pendidikan Seks Anak Usia Dini Perspektif Gender untuk Menghindarkan Sexual Abuse." Jurnal Cakrawala Pendidikan 3, no. 3 (2015): 437-48. https://doi.org/ 10.21831/cp.v3i3.7407.

“Kedungmulyo, Jakenan, Pati,” n.d. https://id.m.wikipedia.org/wiki/Kedungmulyo, Jakenan,_Pati.

Kurniasari, Meiga, Siti Istiyati, and Kartono Kartono. "Pandangan Masyarakat Tani Mengenai Sex Education untuk Anak Usia Dini di Desa Samiran Kecamatan Selo Kabupaten Boyolali." Kumara Cendekia 7, no. 1 (2019): 26-40. https://doi.org/ 10.20961/kc.v7i1.35630.

Laili, Nor, Vivi Mariesca Vibraena, Novira Silmi, Umi Safiul Ummah, and Mohammad Efendi. "Mantuku (Manekin Tubuhku: As an Adaptive Media for Sex Education to Toddlers)." In Proceedings of the 1st International Conference on Early Childhood Care Education and Parenting (ICECCEP 2019). Paris: Atlantis Press, 2020. https://doi.org/10.2991/assehr.k.201205.102.

Lokadata.id. "Kasus Kekerasan Seksual terhadap Anak, 2016-2019." Lokadata.id, 2020. https://lokadata.id/data/kasus-kekerasan-seksual-terhadap-anak-20162019-1578639190.

Mukri, Syarifah Gustiawati. "Pendidikan Seks Usia Dini dalam Derspektif Hukum Islam." Mizan: Journal of Islamic Law 3, no. 1 (2018): 1-20. https://doi.org/ 10.32507/mizan.v3i1.153.

Nawawi, Imam An. Syarah Shahih Muslim Tahqiq \& Takhrij. Translated by Isham AshShababithi and Hazim Muhammad. Jakarta: Pustaka Azzam, 2011.

Nurul, Chomaria. Pendidikan Seks untuk Anak. Solo: Aqwam, 2012.

Purnama, R. Ratna. "Pernah Korban, Guru SD Pelaku Cabul di Depok ingin Balas Dendam," June 8, 2018. https://metro.sindonews.com/berita/1312782/ 170/pernah-korban-guru-sd-pelaku-cabul-di-depok-ingin-balas-dendam. 
Ratnasari, Risa Fitri, and M. Alias. "Pentingnya Pendidikan Seks untuk Anak Usia Dini." Tarbawi Khatulistiwa: Jurnal Pendidikan Islam 2, no. 2 (2016): 55-59. https://doi.org/10.29406/.v2i2.251.

Senja, Atreya. Pendidikan Seks Tanggung Jawab Siapa? The Important of Sex Education for Kids. Yogyakarta: Brilliant, 2020.

Sugiasih, Inhastuti. "Need Assessment mengenai Pemberian Pendidikan Seksual yang Dilakukan Ibu untuk Anak Usia 3-5 Tahun." Proyeksi 6, no. 1 (2011): 71-81.

Sugiyono. Metode Penelitian Pendidikan Pendekatan Kuantitatif, Kualitatif dan R\&D. Bandung: Alfabeta, 2007.

Unite for Children - UNICEF. "Female Genital Mutilation/Cutting: A Global Concern." New York, 2016. http://unfpa.org.co/.

Wathoni, Kharisul. "Persepsi Guru Madrasah Ibtidaiyah tentang Pendidikan Seks bagi Anak (Studi Kasus di MI se-Kecamatan Mlarak).” Kodifikasia 10, no. 1 (2016): 203-27. https://doi.org/10.21154/kodifikasia.v10i1.814.

Yusuf, Madani. Pendidikan Seks Untuk Anak dalam Islam Panduan bagi Orang Tua, Guru dan Kalangan Lainnya. Translated by Iwan Kurniawan and Yudi Yudi. Jakarta: Pustaka Zahra, 2003. 
The page has been intentionally left blank. 